\title{
Characterisation of individual aerosol particles collected during a haze episode in Incheon, Korea using the quantitative ED-EPMA technique
}

\author{
H. Geng ${ }^{1,2}$, J. Y. Ryu ${ }^{1}$, S. Maskey ${ }^{1}$, H.-J. Jung ${ }^{1}$, and C.-U. Ro ${ }^{1}$ \\ ${ }^{1}$ Department of Chemistry, Inha University, Incheon, 402-751, Korea \\ ${ }^{2}$ Research Centre of Environmental Science and Engineering, Shanxi University, Taiyuan, 030006, China \\ Received: 3 September 2010 - Published in Atmos. Chem. Phys. Discuss.: 8 November 2010 \\ Revised: 13 January 2011 - Accepted: 28 January 2011 - Published: 15 February 2011
}

\begin{abstract}
A quantitative energy-dispersive electron probe $\mathrm{X}$-ray microanalysis (ED-EPMA), called low-Z particle EPMA, was used to analyse individual aerosol particles collected in Incheon, Korea on 13-18 October 2008 (a typical haze episode occurred from 15 to 18 October). Overall 3600 individual particles in $\mathrm{PM}_{2.5-10}$ and $\mathrm{PM}_{1.0-2.5}$ fractions from 12 aerosol samples collected on haze and non-haze days were analysed. The analysed particles were classified, based on their X-ray spectral data together with their secondary electron images. The major particle types included organic carbon (OC), elemental carbon (EC), sea-salt, mineral dust (such as aluminosilicate, $\mathrm{SiO}_{2}, \mathrm{CaCO}_{3} / \mathrm{CaMgCO}_{3}$, etc.), $\left(\mathrm{NH}_{4}\right)_{2} \mathrm{SO}_{4} / \mathrm{NH}_{4} \mathrm{HSO}_{4}$-containing, K-containing, $\mathrm{Fe}$ rich and fly ash particles. Their relative number abundance results showed that OC particles were significantly increased while sea-salts and mineral dust particles were significantly decreased (especially in $\mathrm{PM}_{1.0-2.5}$ fraction) when haze occurred. For the other particle types (except Fe-rich particles in $\mathrm{PM}_{2.5-10}$ fraction), there were no significant differences in their relative abundances between haze and non-haze samples. On non-haze days, the nitrate-containing reacted seasalt and mineral dust particles in $\mathrm{PM}_{1.0-2.5}$ fraction significantly outnumbered the sulfate-containing ones, whereas it was the reverse on haze days, implying that on haze days there were special sources or formation mechanisms for fine aerosol particles $(\leq 2.5 \mu \mathrm{m}$ in aerodynamic diameter). The emission of air pollutants from motor vehicles and stagnant meteorological conditions, such as low wind speed and high relative humidity, might be responsible for the elevated level of OC particles on haze days.
\end{abstract}

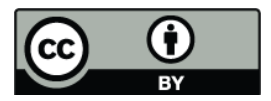

Correspondence to: C.-U. Ro (curo@inha.ac.kr)

\section{Introduction}

Urban haze, an atmospheric phenomenon that leads to low visibility, has increased in occurrence over the last several years over the Seoul-Incheon metropolis and other cities in Korea, because of continuous economic growth and the increased consumption of fossil fuels (Lee et al., 2006; Chun and Lim, 2004; Kim et al., 2008). The occurrence of haze is closely related to meteorological conditions and air pollution (Keywood et al., 2003). Specifically, the formation of haze is favoured by stagnant weather conditions and high emissions of air pollutants (Sun et al., 2006). For instance, under a temperature inversion, airborne smog, organic compounds, and particulate matter often fail to diffuse, persisting in the air over the city and, thus, inducing haze (Viezee and Oblanas, 1969). In general, urban haze is related to a high level of airborne particles resulting from anthropogenic emission (through industrial and other human activities) and from gas-to-particle conversion (Watson, 2002). In turn, haze alters the composition of airborne aerosols through aqueous phase reactions (Sun et al., 2006), having significant effects on visibility, cloud formation, public health and even the global climate (Davis et al., 2010; Yadav et al., 2003; Menon et al., 2002; Lee and Sequeira, 2001).

In Korea, the low-visibility days are defined when the horizontal visibility is less than $6 \mathrm{~km}$ due to mist, haze or fog (Chung et al., 1999). The annual number of low-visibility days has significantly increased due to the frequent occurrence of fog, mist and haze (caused largely by increasing emission of anthropogenic air pollutants such as fine particles, $\mathrm{NO}_{\mathrm{x}}, \mathrm{SO}_{2}$ and organic compounds), especially in urban areas (Kim et al., 2008). Several studies on the spatial variation of visibility and climatic characteristics of haze episodes in the Seoul-Incheon metropolis have been carried out (Chun and Lim, 2004; Kang et al., 2004). It was reported that haze phenomenon mainly occurred when the

Published by Copernicus Publications on behalf of the European Geosciences Union. 


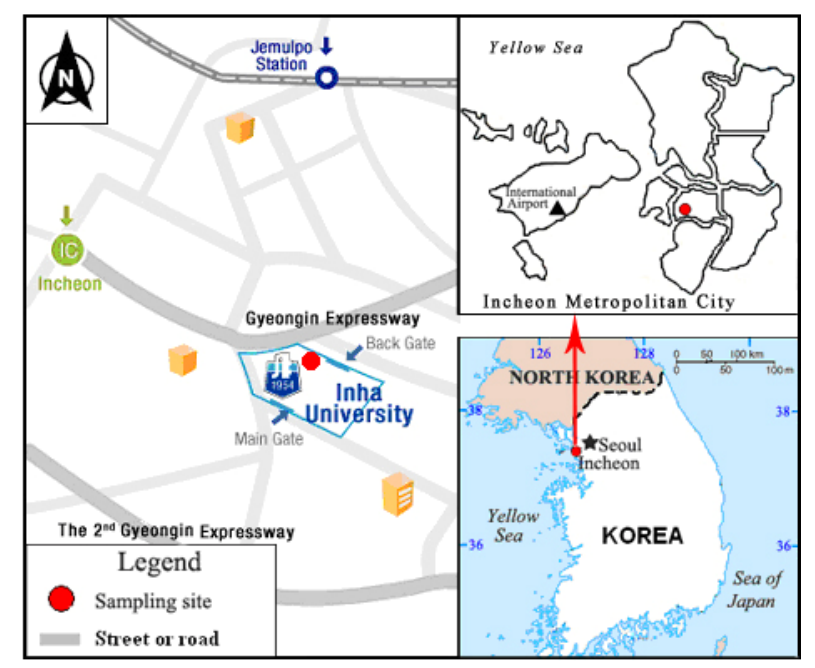

Fig. 1. A schematic map of the sampling site.

Korean peninsula was under the effect of the anticyclone and lasted longer when the lower atmosphere became stable and the wind speed was weak (Chun and Lim, 2004). During urban haze episodes, water-soluble inorganic ions (such as $\mathrm{NO}_{3}^{-}, \mathrm{SO}_{4}^{2-}$, and $\mathrm{NH}_{4}^{+}$) and carbonaceous species in $\mathrm{PM}_{2.5}$ are considered important contributors to visibility impairment (Kang et al., 2004; Jacobson et al., 2001). It has been reported that in fine particle mass loading on haze days, ammonium sulfate and organic carbon (OC) are dominant (Kim et al., 2008; Brown et al., 2002); on the other hand, haze decline shows consistency with the reduction of $\mathrm{PM}_{2.5}$ and sulfur emissions (Schichtel et al., 2001).

Although attention has been paid to the haze phenomenon for decades, the chemical characteristics and morphologies of individual airborne particles on haze days in the SeoulIncheon metropolis have rarely been investigated. In fact, such studies are needed because (1) the detailed information on homogeneous/heterogeneous aerosol particles' microphysical and chemical properties can deepen our understanding of the sources, reactivity, transport and removal of airborne particles; (2) it can reflect the influence of continental outflow events on aerosol compositions, since Incheon, located on the west coast of Korea, is one of the Korean cities nearest to China, being frequently impacted by air masses originating from Mongolia and China.

In the present work, a quantitative energy-dispersive electron probe X-ray microanalysis (ED-EPMA) method, called low-Z particle EPMA, was used to characterise ambient aerosol particles collected in Incheon on haze and non-haze days. This single-particle analytical technique, which is based on scanning electron microscopy (SEM) coupled with an ultra-thin window energy-dispersive X-ray spectrometer (EDX), can not only simultaneously detect the morphology and constituent elements of a single particle, but also provide transformation information on many environmentally- important particles of micrometer size, such as nitrates, sulfates, oxides or mixtures, including carbon matrices (Kim and Ro, 2010; Choel et al., 2005; Geng et al., 2010).

The objective of the present study was to identify the ambient aerosol particle types and compare their relative abundance distribution during a typical haze episode (occurring on 15-18 October, 2008) with that on non-haze days by using low-Z particle EPMA, and to investigate possible contributing factors to haze formation in Incheon, Korea.

\section{Materials and methods}

\subsection{Sampling}

Incheon, located on the coast of the Yellow Sea, is densely populated, with 2.7 million people in an area of $958 \mathrm{~km}^{2}$. It is the third largest metropolis and one of the most important transport hubs in Korea. A part of Incheon borders the capital city and the Seoul-Incheon subway systems are linked, so Incheon is considered a part of the greater Seoul metropolitan area. Incheon has many different local emission sources, including seven industrial complexes, two seaports with ten wharfs and one international airport. The sampling site, regarded as being susceptible to various urban source processes, was located on the roof of a five-story building (about $20 \mathrm{~m}$ above the ground) of Inha University, Incheon (latitude $37.45^{\circ} \mathrm{N}$, longitude $126.73^{\circ} \mathrm{E}$, see Fig. 1). Aerosol particles were collected on $\mathrm{Al}$ foils by using a three-stage cascade impactor (Dekati PM-10 sampler, Dekati Ltd.). At a flow rate of $10 \mathrm{~L} \mathrm{~min}^{-1}$, the aerodynamic cut-off diameters for stages $1-3$ were $>10,2.5-10$ and $1.0-2.5 \mu \mathrm{m}$, respectively. Overall, 12 sets of samples were obtained in the morning and evening on 13-18 October 2008. Particles collected on stages 2 and 3 were analysed for each sample set, since particles in the size range of $1.0-10 \mu \mathrm{m}$ in diameter have more contributions to haze formation and health damage than particles which are bigger than $10 \mu \mathrm{m}$. Hence, particles on stage 1 were neglected in the study. The collection duration for each stage sample was controlled so that particles were collected without overloading. Sampling dates, temperature $(T), \mathrm{RH}$, average wind speed and weather status (haze or not) during the sampling are given in Table 1.

The 72-h backward air-mass trajectories at a receptor height of $40 \mathrm{~m}$ a.s.l. were produced using the HYbrid Single-Particle Lagrangian Integrated Trajectory (HYSPLIT4) model available at the NOAA Air Resources Laboratory's web server (http://www.arl.noaa.gov/ready/hysplit4. html) (Fig. 2).

\subsection{Data measurement and analysis}

A swatch of $\mathrm{Al}$ foil containing the sample particles was cut and observed. The measurements were carried out on a JEOL JSM-6390 SEM equipped with an Oxford Link SATW ultrathin window EDX detector. The resolution of the detector 


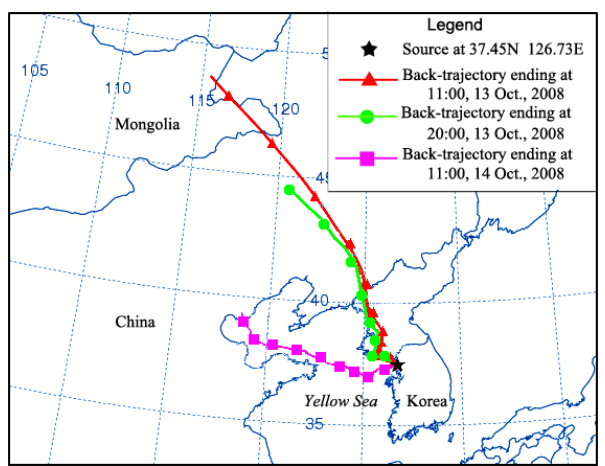

(a) 13-14 Oct. 2008

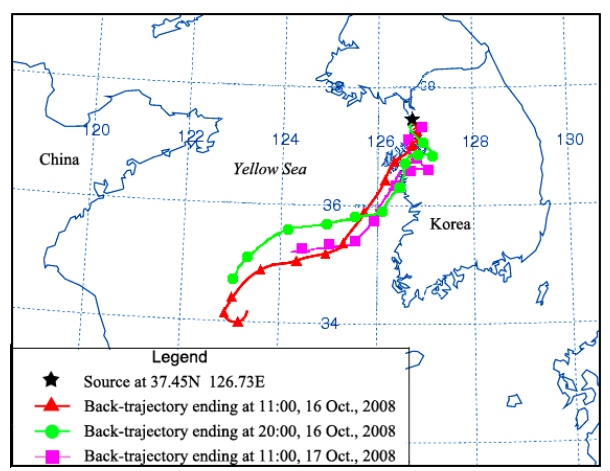

(c) $16-17$ Oct. 2008

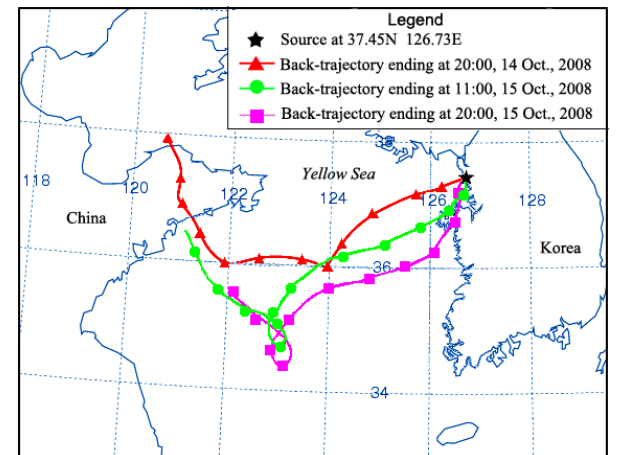

(b) $14-15$ Oct. 2008

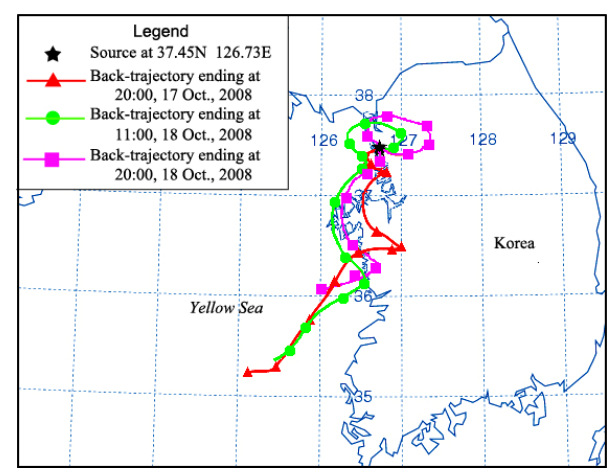

(d) $17-18$ Oct. 2008

Fig. 2. 72-h backward air-mass trajectories at sampling height (around $40 \mathrm{~m}$ a.s.1.) from 13 to 18 October 2008 (KST).

Table 1. Sampling time and meteorological conditions during sampling.

\begin{tabular}{llrrrrr}
\hline No. & sampling date & $\begin{array}{r}\text { Local time } \\
(\mathrm{KST})\end{array}$ & $\begin{array}{r}\text { Temperature } \\
\left({ }^{\circ}\right)\end{array}$ & $\begin{array}{r}\text { RH } \\
(\%)\end{array}$ & $\begin{array}{r}\text { Wind speed } \\
\left(\mathrm{m} \mathrm{s}^{-1}\right)\end{array}$ & $\begin{array}{l}\text { Weather } \\
\text { status }\end{array}$ \\
\hline$(1)$ & a.m. 13 October 2008 & $10: 15 \sim 11: 45$ & 17.9 & 56 & 2.0 & Non-haze \\
$(2)$ & p.m. 13 October 2008 & $19: 00 \sim 20: 11$ & 16.8 & 68 & 1.9 & Non-haze \\
$(3)$ & a.m. 14 October 2008 & $10: 05 \sim 11: 50$ & 19.3 & 58 & 2.1 & Non-haze \\
$(4)$ & p.m. 14 October 2008 & $19: 03 \sim 20: 00$ & 17.7 & 69 & 1.8 & Non-haze \\
$(5)$ & a.m. 15 October 2008 & $10: 10 \sim 11: 30$ & 19.4 & 73 & 1.5 & Non-haze \\
$(6)$ & p.m. 15 October 2008 & $18: 55 \sim 20: 30$ & 18.1 & 81 & 1.1 & haze \\
$(7)$ & a.m. 16 October 2008 & $10: 10 \sim 11: 00$ & 19.8 & 67 & 0.8 & haze \\
$(8)$ & p.m. 16 October 2008 & $19: 12 \sim 20: 34$ & 18.6 & 92 & 1.2 & haze \\
$(9)$ & a.m. 17 October 2008 & $10: 10 \sim 11: 30$ & 18.9 & 79 & 2.0 & haze \\
$(10)$ & p.m. 17 October 2008 & $19: 30 \sim 21: 05$ & 18.7 & 90 & 1.4 & haze \\
$(11)$ & a.m. 18 October 2008 & $10: 06 \sim 10: 50$ & 20.1 & 68 & 0.7 & haze \\
$(12)$ & p.m. 18 October 2008 & $19: 40 \sim 20: 45$ & 20.0 & 75 & 1.0 & haze \\
\hline
\end{tabular}

was $133 \mathrm{eV}$ for a $\mathrm{Mn}-\mathrm{K} \alpha \mathrm{X}$-ray. X-ray spectra were recorded under the control of INCA software (Oxford), with an accelerating voltage of $10 \mathrm{kV}$ and a beam current of $0.5 \mathrm{nA}$. The size, secondary electron image (SEI), chemical compositions and the mixing state of 150 individual particles for each stage sample (3600 particles overall for 24 stage samples) were investigated manually. The net characteristic X-ray intensities of chemical elements were evaluated by a nonlinear leastsquares fitting using the AXIL programme (Vekemans et al., 1994). A Monte Carlo simulation with successive approximation was used for quantification (Ro et al., 2003). The elemental quantification procedure provided results with an accuracy of within $12 \%$ relative deviations between the calculated and nominal elemental concentrations for the standard 
Table 2. Classification of aerosol particles based on SEI and X-ray data.

\begin{tabular}{|c|c|c|c|}
\hline Particle types & $\begin{array}{l}\text { Characteristics of } \\
\text { morphology and } \\
\text { chemical compositions }\end{array}$ & Possible sources & $\begin{array}{l}\text { Corresponding particles } \\
\text { in Fig. } 3\end{array}$ \\
\hline (1) genuine mineral dust & $\begin{array}{l}\text { Appearing irregular } \\
\text { and bright on their } \\
\text { SEIs and having definite } \\
\text { X-ray signals, } \\
\text { including alminosilicate, } \\
\mathrm{SiO}_{2}, \mathrm{CaCO}_{3} \text {, and } \\
\mathrm{CaMg}\left(\mathrm{CO}_{3}\right)_{2} \text {. }\end{array}$ & soil or construction site & $\begin{array}{l}\text { particles \#8, \#11, \#22, } \\
\# 37, \quad \# 50, \# 58, \quad \# 62, \\
\text { and etc. }\end{array}$ \\
\hline (2) reacted mineral dust & $\begin{array}{l}\text { They are often enclosed } \\
\text { by liquid droplet on } \\
\text { SEIs; } \mathrm{N} \text { and } \mathrm{S} \text { signals } \\
\text { can be detected in their } \\
\mathrm{X} \text {-ray spectra. Reacted } \\
\mathrm{CaCO}_{3} / \mathrm{CaMg}\left(\mathrm{CO}_{3}\right)_{2} \\
\text { and aluminosilicate with } \\
\text { nitrate/sulfate are the } \\
\text { main species. }\end{array}$ & $\begin{array}{l}\text { reaction of mineral } \\
\text { dust with airborne } \\
\mathrm{NO}_{\mathrm{x}} / \mathrm{HNO}_{3} \text { and } \\
\mathrm{SO}_{2} / \mathrm{H}_{2} \mathrm{SO}_{4}\end{array}$ & $\begin{array}{l}\text { nitrate-containing parti- } \\
\text { cles \#1, \#9-13, \#102- } \\
104 \text {; sulfate-containing } \\
\text { particles \#31, \#35, \#70, } \\
\# 75, \# 78, \# 90 \text {, and \#92 }\end{array}$ \\
\hline $\begin{array}{l}\text { (3) genuine (or fresh) } \\
\text { sea-salt }\end{array}$ & $\begin{array}{l}\mathrm{Na} \text { and } \mathrm{Cl} \text { signals are } \\
\text { predominant, often with } \\
\text { minor } \mathrm{C}, \mathrm{O} \text {, and } \mathrm{Mg} \text {. }\end{array}$ & $\begin{array}{l}\text { bubble bursting or sea } \\
\text { spray process from } \\
\text { ocean }\end{array}$ & particle \#2 \\
\hline $\begin{array}{l}\text { (4) reacted (or aged) sea- } \\
\text { salt (and mixtures) }\end{array}$ & $\begin{array}{l}\text { Containing } \mathrm{NO}_{3}^{-} \text {and/or } \\
\mathrm{SO}_{4}^{2-} \text { in addition to } \mathrm{Na} \text {, } \\
\mathrm{Cl} \text {, and } \mathrm{Mg} \text { (sometimes } \\
\text { mixed with mineral dust) }\end{array}$ & $\begin{array}{l}\text { reaction of sea-salt with } \\
\text { airborne } \mathrm{NO}_{\mathrm{x}} / \mathrm{HNO}_{3} \text { and } \\
\mathrm{SO}_{2} / \mathrm{H}_{2} \mathrm{SO}_{4}\end{array}$ & $\begin{array}{l}\text { nitrate-containing parti- } \\
\text { cles \#6, \#43, and \#100; } \\
\text { sulfate-containing parti- } \\
\text { cles \#67 and \#98 }\end{array}$ \\
\hline $\begin{array}{l}\text { (5) carbon-rich or } \\
\text { elemental carbon (EC) }\end{array}$ & $\begin{array}{l}\text { The sum of }[\mathrm{C}] \text { and }[\mathrm{O}] \\
\text { is more than } 90 \text { at. } \% \text {, and } \\
{[\mathrm{C}] \text { is } 3 \text { times larger than }} \\
{[\mathrm{O}] \text {. }}\end{array}$ & & \\
\hline (a) soot aggregates & $\begin{array}{l}\text { A fractal-like structure, } \\
\text { sometimes being } \\
\text { surrounded by organic } \\
\text { matter }\end{array}$ & combustion & $\begin{array}{l}\text { particles \#16, \#68, and } \\
\# 82\end{array}$ \\
\hline (b) tar ball & $\begin{array}{l}\text { Separated bright } \\
\text { spherules on SEI }\end{array}$ & smoldering combustion & $\begin{array}{l}\text { particles \#26, \#39, and } \\
\# 129\end{array}$ \\
\hline (c) char or coal dust & $\begin{array}{l}\text { Irregular-shaped bright } \\
\text { structure on SEI }\end{array}$ & $\begin{array}{l}\text { natural origin or } \\
\text { combustion }\end{array}$ & particles \#56 \\
\hline (6) organic carbon (OC) & $\begin{array}{l}\text { The sum of }[\mathrm{C}] \text { and }[\mathrm{O}] \\
\text { (sometimes }[\mathrm{N}] \text { ) is more } \\
\text { than } 90 \text { at. } \% \text {, and }[\mathrm{C}] \text { is } \\
\text { comparable to }[\mathrm{O}] .\end{array}$ & & \\
\hline $\begin{array}{l}\text { (a) water-insoluble or } \\
\text { solid organic particles }\end{array}$ & $\begin{array}{l}\text { Containing high levels of } \\
\mathrm{C} \text { and } \mathrm{O} \text { or } \mathrm{C}, \mathrm{O} \text {, and } \mathrm{S} \text {; } \\
\text { looking bright and angu- } \\
\text { lar on SEI }\end{array}$ & $\begin{array}{l}\text { combustion processes, } \\
\text { biogenic, and primary } \\
\text { or secondary aerosol } \\
\text { products }\end{array}$ & $\begin{array}{l}\text { particles \#14, \#38, \#42, } \\
\# 49, \quad \# 59-61, \# 63-65, \\
\# 69, \# 71-74, \# 79, \# 80, \\
\# 83, \# 84, \text { and \#86 }\end{array}$ \\
\hline $\begin{array}{l}\text { (b) } \mathrm{CO} / \mathrm{COS} \text {-rich } \\
\text { droplets }\end{array}$ & $\begin{array}{l}\text { Liquid droplet particles } \\
\text { rich in } \mathrm{C}, \mathrm{O} \text {, and } \mathrm{S} \\
\text { (occasionally only } \mathrm{C} \text { and } \\
\mathrm{O} \text { ), probably containing } \\
\text { water-soluble secondary } \\
\text { organic aerosol } \\
\text { (WSOA); looking dark } \\
\text { and round on SEI }\end{array}$ & $\begin{array}{l}\text { oxidation of volatile or- } \\
\text { ganic compounds, hu- } \\
\text { mic or humic-like sub- } \\
\text { stances, and incomplete } \\
\text { combustion of fossil fu- } \\
\text { els and biomass }\end{array}$ & $\begin{array}{l}\text { particles } \# 19, \# 21, \# 25, \\
\# 29, \# 30, \# 32, \# 33, \# 34, \\
\# 106, \# 111, \# 123,125, \\
\# 128, \# 131, \text { and } \# 133\end{array}$ \\
\hline
\end{tabular}


Table 2. Continued.

\begin{tabular}{|c|c|c|c|}
\hline Particle types & $\begin{array}{l}\text { Characteristics of } \\
\text { morphology and } \\
\text { chemical compositions }\end{array}$ & Possible sources & $\begin{array}{l}\text { Corresponding particles } \\
\text { in Fig. } 3\end{array}$ \\
\hline $\begin{array}{l}(7)\left(\mathrm{NH}_{4}\right)_{2} \mathrm{SO}_{4} / \mathrm{NH}_{4} \mathrm{HSO}_{4} \\
\text {-containing particles }\end{array}$ & $\begin{array}{l}\text { Liquid or solid particles } \\
\text { rich in } \mathrm{C}, \mathrm{N}, \mathrm{O} \text {, and } \mathrm{S} \text {; } \\
\text { sensitive to electron beam }\end{array}$ & $\begin{array}{l}\text { reaction of ambient } \\
\mathrm{H}_{2} \mathrm{SO}_{4} / \mathrm{SO}_{4}^{2-} \text { with } \mathrm{NH}_{3}\end{array}$ & $\begin{array}{l}\text { particles \#124, \#130, and } \\
\# 132\end{array}$ \\
\hline (8) Fly ash particles & $\begin{array}{l}\text { Tiny glass spheres that are } \\
\text { composed of mostly silicon, } \\
\text { aluminum, iron, and/or cal- } \\
\text { cium oxides. }\end{array}$ & $\begin{array}{l}\text { coal combustion in } \\
\text { power plants (high } \\
\text {-temperature } \\
\text { combustion) }\end{array}$ & $\begin{array}{l}\text { particles \#76, \#85, and } \\
\# 97\end{array}$ \\
\hline $\begin{array}{l}\text { (9) K-containing } \\
\text { particles }\end{array}$ & $\begin{array}{l}\text { Irregular-shaped particles } \\
\text { containing } \mathrm{K}_{2} \mathrm{SO}_{4}, \mathrm{KCl} \text {, or } \\
\mathrm{K}_{2} \mathrm{CO}_{3}\end{array}$ & $\begin{array}{l}\text { mostly from biomass } \\
\text { burning }\end{array}$ & $\begin{array}{l}\text { particles \#24, \#36, \#77, } \\
\# 88 \text {, and \#99 }\end{array}$ \\
\hline (10) Fe-rich particles & $\begin{array}{l}\text { Looking bright on their } \\
\text { SEIs, usually containing } \\
\text { more than } 20 \text { at. } \% \text { of Fe, } \\
\text { sometimes with minor C, } \\
\mathrm{Si} \text {, and } \mathrm{Al}\end{array}$ & $\begin{array}{l}\text { steel production, metal- } \\
\text { lurgical industries, min- } \\
\text { ing, and abrasion } \\
\text { of brake lining }\end{array}$ & particles \#3 and \#7 \\
\hline
\end{tabular}

particles (Ro et al., 2000, 2001). The "expert system" programme, which can rapidly and reliably perform chemical speciation, was used to determine the formula concentrations and particle group distributions (Ro et al., 2004).

The basic classification rules are briefly summarized here. Firstly, a particle was regarded as being composed of just one chemical species if this species constituted at least $90 \%$ in atomic fraction. Secondly, chemical species were specified for particles internally mixed with two or more chemical species. Thirdly, elements with less than 1.0 at.\% (atomic percent concentration) were neglected, since elements at trace levels cannot be reliably investigated using ED-EPMA. The speciation of carbonaceous particles was carried out based on particles' morphologies and the $\mathrm{C}$ and $\mathrm{O}$ contents. When the sum of $\mathrm{C}$ and $\mathrm{O}$ contents for a particle was larger than $90 \%$ in atomic concentration, it was regarded as an organic or carbon-rich particle (Ro et al., 2005). Although the presence of hydrogen fails to be detected in EPMA, elemental carbon (EC) and organic carbon (OC) can be identified in a somewhat arbitrary way. For EC particles (also called carbon-rich particles), atomic concentration of $\mathrm{C}$ is 3 times larger than that of $\mathrm{O}$. The different types of EC particles, such as soot aggregate, tar ball and char or coal dust, can be easily identified from their morphology on SEI. For OC particles, atomic concentration of $\mathrm{C}$ is comparable to that of $\mathrm{O}$, and $\mathrm{N}$ signal is often detected.

\section{Results and discussion}

\subsection{Particle types}

In this work, analysed particles were classified based on their X-ray spectral and SEI data. Particle types that were abundantly observed in the samples were carbonaceous (including EC and OC), mineral dust, sea-salt, $\left(\mathrm{NH}_{4}\right)_{2} \mathrm{SO}_{4} / \mathrm{NH}_{4} \mathrm{HSO}_{4}{ }^{-}$ containing, K-containing, fly ash and Fe-rich particles. The characteristics and possible sources of each particle type are described in Table 2. The field images for particles collected before and during the haze episode are shown in Fig. 3. Although the morpholgies of tar balls and chars are quite different from that of soot aggregates, the X-ray spectra of the three types of EC particles are similar (Fig. 4) and the concentration ratio of $\mathrm{C}$ and $\mathrm{O}$ for $\mathrm{EC}$ particles is always larger than that for OC particles (Figs. 4 and 5).

\subsection{Relative abundances of various types of particles}

Urban areas generally undergo high pollution loads, from sources including heavy traffic, emissions from industrial plants and intensive energy consumption, which leads to complicated compositions of atmospheric particles. Incheon, one of the largest seaports and cities in Korea, has been facing air pollution problems with its steady increase of fossil fuel consumption. The number of low visibility days has significantly increased due to the frequent occurrence of fog, mist and haze, which is related to the elevated anthropogenic air pollution and water vapour in the study area (Chung et al., 1999). When haze occurred, not only was mass concentration of airborne $\mathrm{PM}_{10}$ (especially $\mathrm{PM}_{2.5}$ ) increased, but also the components of aerosol particles were changed in comparison with the non-haze days (Jung et al., 2009; Noh et al., 2004; Hong et al., 2008; Lee et al., 2006). The characteristics of aerosol components can be inferred from the particle types' relative abundances, which were obtained by dividing the number of a specific type of particle by the total number of particles analysed for a sample (Fig. 6). And the comparison of relative abundances of major particle types between haze and non-haze samples can give the indication of what is responsible for the haze formation.

As shown in Table 3, for $\mathrm{PM}_{2.5-10}$ fraction, the reacted sea-salt and reacted mineral dust particles (with $\mathrm{NO}_{\mathrm{x}}$ and/or 
Table 3. Relative abundances of major particle types on haze vs. non-haze days.

\begin{tabular}{|c|c|c|c|c|}
\hline \multirow[t]{2}{*}{ Particle types } & \multicolumn{2}{|c|}{$\begin{array}{r}\text { Relative abundances } \\
\text { in } \mathrm{PM}_{2.5-10} \text { fraction (\%) }\end{array}$} & \multicolumn{2}{|c|}{$\begin{array}{r}\text { Relative abundances } \\
\text { in } \mathrm{PM}_{1.0-2.5} \text { fraction (\%) }\end{array}$} \\
\hline & non-haze days & haze days & non-haze days & haze days \\
\hline (1) genuine mineral dust & $10.3 \pm 3.4$ & $12.7 \pm 5.4$ & $9.3 \pm 5.0$ & $5.8 \pm 5.5$ \\
\hline (2) reacted mineral dust & $46.0 \pm 2.7$ & $49.5 \pm 9.2$ & $29.7 \pm 11.2^{\mathrm{a}}$ & $10.6 \pm 8.6$ \\
\hline (3) genuine sea-salt & $1.1 \pm 1.6$ & $0.5 \pm 0.9$ & $0.8 \pm 1.1$ & $0.6 \pm 1.1$ \\
\hline (4) reacted sea-salt (and mixtures) & $25.1 \pm 6.9$ & $15.5 \pm 9.6$ & $28.0 \pm 8.5^{\mathrm{b}}$ & $6.9 \pm 3.7$ \\
\hline (5) elemental carbon (EC) & $2.8 \pm 2.1$ & $3.2 \pm 2.1$ & $5.9 \pm 4.4$ & $5.1 \pm 3.1$ \\
\hline (6) organic carbon $(\mathrm{OC})$ & $3.0 \pm 2.2^{\mathrm{a}}$ & $9.8 \pm 4.9$ & $13.1 \pm 7.0^{\mathrm{b}}$ & $58.7 \pm 19.8$ \\
\hline (7) $\left(\mathrm{NH}_{4}\right)_{2} \mathrm{SO}_{4} / \mathrm{NH}_{4} \mathrm{HSO}_{4}$-containing & $0.5 \pm 0.7$ & $1.4 \pm 1.8$ & $2.4 \pm 1.7$ & $5.5 \pm 4.3$ \\
\hline (8) fly ash & $3.8 \pm 2.8$ & $2.5 \pm 1.7$ & $4.3 \pm 2.6$ & $1.2 \pm 1.5$ \\
\hline (9) K-containing & $2.0 \pm 1.5$ & $1.9 \pm 3.1$ & $4.2 \pm 4.3$ & $3.8 \pm 2.3$ \\
\hline (10) Fe-rich & $5.4 \pm 1.5^{\mathrm{a}}$ & $3.0 \pm 1.5$ & $2.3 \pm 1.9$ & $1.9 \pm 2.8$ \\
\hline
\end{tabular}

Note: (1) The non-haze samples were collected on 13 and 14 October 2008 and in the morning of 15 October 2008; the haze samples were collected in the afternoon of 15 October 2008 and on $16-18$ October 2008.

(2) The student $t$-test was used to compare the difference of relative abundances for different particle types between haze and non-haze days. The difference was regarded as significant when ${ }^{\mathrm{a}} P \leq 0.05 ;{ }^{\mathrm{b}} P \leq 0.01$.

(3) The data are expressed as "mean \pm S.D.".

$\mathrm{SO}_{2}$ ), which greatly outnumber the genuine (fresh) ones, are most frequently encountered with average relative abundances of $71.1 \%$ and $65.0 \%$ on non-haze and haze days, respectively, indicating that anthropogenic $\mathrm{NO}_{\mathrm{x}}$ and/or $\mathrm{SO}_{2}$ made great impacts on chemical compositions of aerosol particles in urban atmosphere. In this size range, there is no significant difference in their relative abundances between haze and non-haze samples (by student $t$-test, as shown in Table 3) for genuine and reacted sea-salt, genuine and reacted mineral dust, EC, fly ash and K-containing particles. But for OC particles, their abundance on haze days, though not very large, significantly outweighs that on non-haze days (on average, $9.8 \%$ vs. $3.0 \%$ in relative abundance). And Fe-rich particles are significantly reduced on haze days (reduced from $5.4 \%$ to $3.0 \%$ ).

For $\mathrm{PM}_{1.0-2.5}$ fraction, the relative abundance of OC particles on haze days is significantly increased (on average, $58.7 \%$ vs. $13.1 \%$ ), while the abundance of reacted sea-salt and reacted mineral dust particles is significantly reduced, compared to that on non-haze days (on average, $17.5 \%$ vs. $57.7 \%$ ) (Table 3). Especially for the haze sample "16_PM", nearly all the particles are OC species (Fig. 6). There is no significant difference in their respective relative abundances between haze and non-haze samples for genuine sea-salt, genuine mineral dust, EC, fly ash, Fe-rich, K-containing and $\left(\mathrm{NH}_{4}\right)_{2} \mathrm{SO}_{4} / \mathrm{NH}_{4} \mathrm{HSO}_{4}$-containing particles.

The above results indicate that haze occurrence is attributable to the increase of ambient OC particles (especially smaller than $2.5 \mu \mathrm{m}$ in diameter). Possible explanations for the elevated level of OC particles during the haze episode and their origins are suggested as follows:
1. It is hypothesized that air pollutants emitted from motor vehicles in Incheon, but not from biomass burning, were a significant factor in haze formation. Although chemical analysis has shown that the major aerosol constituents in haze phenomena at Syowa Station, Antarctica, were sea-salts (e.g., $\mathrm{Na}^{+}, \mathrm{Cl}^{-}$) (Hara, et al., 2010), either genuine or reacted sea-salt particles were not abundantly observed in the Incheon haze samples (although Incheon is located near the Yellow sea). It is suggested that haze formation in Incheon had a unique mechanism (not owing to the increase of sea-salt aerosols). Since Incheon is one of the largest cities in Korea, densely populated with about 700000 motor vehicles (still sharply increasing in number due to rapid urbanization and motorization, Timilsina and Shrestha, 2009), and motor vehicle exhaust accounted for $>80 \%$ of the air pollution in the area (Kim et al., 2006), much of the organic aerosol burden in Incheon can be attributed to automotive vehicle sources. For example, a number of freight vehicles, i.e., heavy-duty trucks (diesel vehicles), travel along the highway carrying goods to the wharves at Incheon seaport; most of the short-term transients for commuting are attributable to local traffic sources. The higher OC and EC levels are often observed during the morning traffic hours (Kim et al., 2006).

Many studies have reported that the relatively high level of water-soluble potassium $\left(\mathrm{K}^{+}\right)$is present in biomass burning plumes and, therefore, potassium has been widely used as a tracer of biomass burning in sourceapportionment studies (Wang et al., 2007; Andreae, 1983). However, in the present study, no significant 

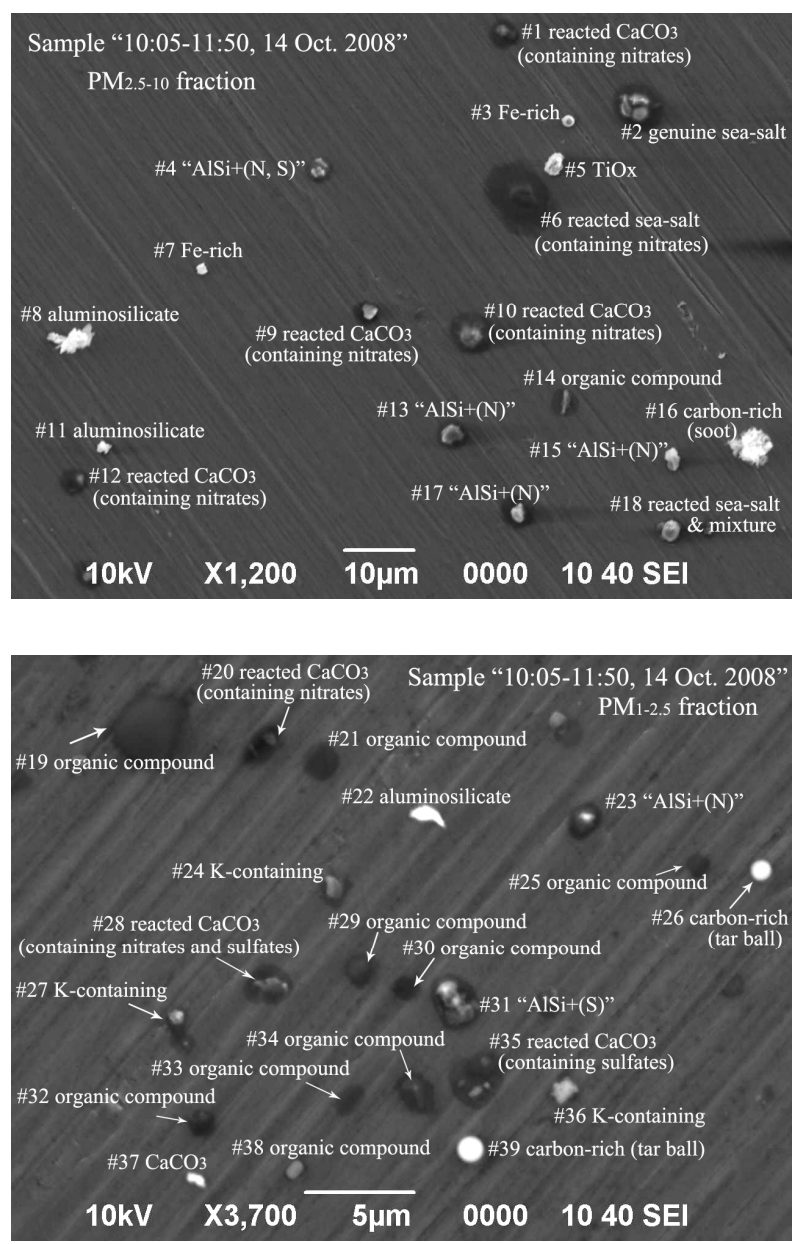

(a)

Fig. 3a. Typical SEM images of urban aerosol particles collected in Incheon, Korea. (For convenience, aluminosilicate is denoted as "AlSi-containing". "(N)" notation represents particles containing nitrates; "(S)" notation represents particles containing sulfates; "(N, S )" notation represents particles containing both nitrates and sulfates. (C, N, O, S) notation represents the mixture of carbonaceous and $\left(\mathrm{NH}_{4}\right)_{2} \mathrm{SO}_{4} / \mathrm{NH}_{4} \mathrm{HSO}_{4}$ particles.)

difference in the relative abundances of K-containing particles between samples collected on haze and nonhaze days was observed (Table 3 and Fig. 6), implying that biomass burning was not a major contributor to this haze episode although biomass burning events could greatly degrade the local air quality and could cause long-lasting regional haze phenomena under stagnant atmospheric conditions (Ryu et al., 2007).

2. It is likely that secondary OC particles account for the majority of the organic compounds, resulting in haze occurrence. It is known that meteorological factors such as weak winds, high RH and temperature and "fumigation" along the coast play important roles in the formation of secondary aerosol particles and haze (Soleiman
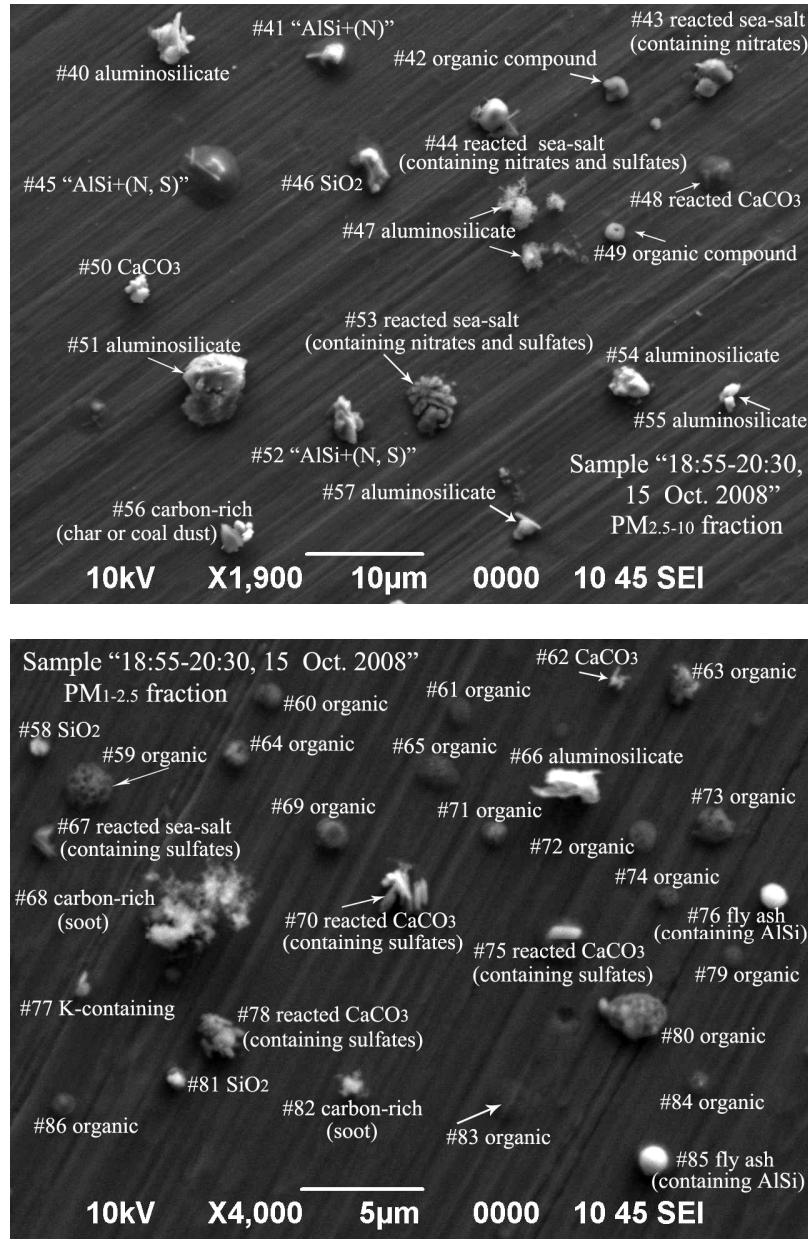

(b)

Fig. 3b. Continued.

et al., 2003). Under stagnant meteorological conditions of slow wind speed and high RH, ultrafine particles converted from gaseous species could remain for a longer time and hygroscopic particles could grow to become larger ones, which favours haze formation (Carrico et al., 2010). As wind speeds were slower and RHs were higher $(\mathrm{RH}=67 \%-92 \%)$ on haze days than on non-haze days (Table 1), formation of secondary OC particles (probably produced by photochemical smog or photochemical reactions) is favoured. Kang et al. (2004) and Noh et al. (2009) reported that the fine aerosols responsible for haze formation are mostly secondary OC particles based on the investigation of chemical characteristics of acidic gas pollutants and $\mathrm{PM}_{2.5}$ during hazy episodes in Seoul, Korea.

3. The different compositional characteristics of reacted sea-salt and reacted mineral dust particles between haze and non-haze samples indicate that the mechanism for secondary aerosol formation on haze days might be different from that on non-haze days. On non-haze 


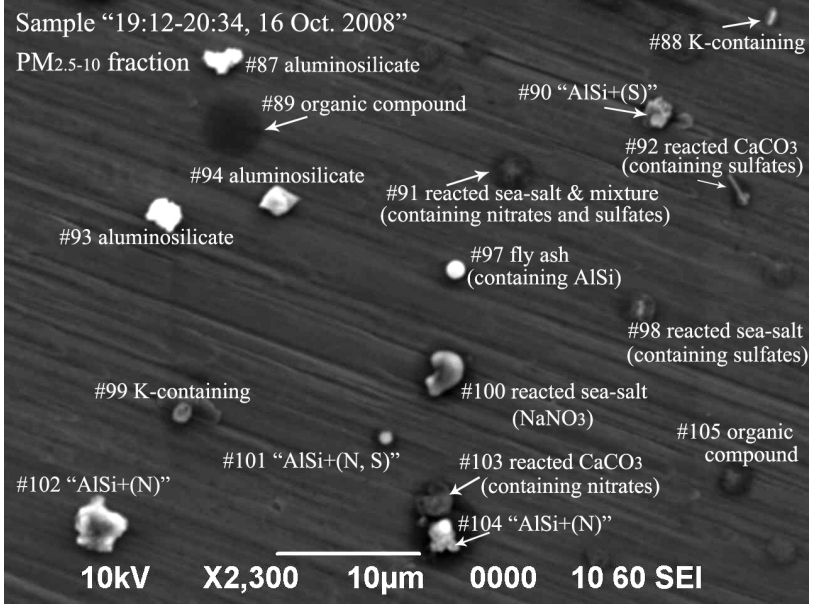

(c)

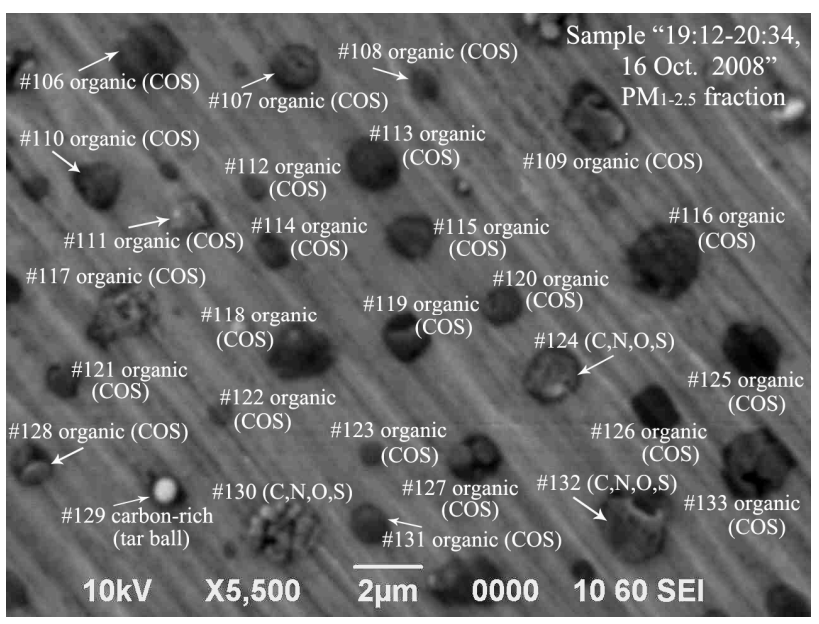

Fig. 3c. Continued.

days, nitrate-containing species both in reacted sea-salt and reacted mineral dust particles significantly outnumber sulfate- and both (nitrate and sulfate)-containing species, both for $\mathrm{PM}_{2.5-10}$ or $\mathrm{PM}_{1.0-2.5}$ fractions (see Fig. 7), indicating that $\mathrm{NO}_{\mathrm{x}}$ in the atmosphere has more influence on compositions of aerosol particles, probably due to its higher local mass concentration than that of local $\mathrm{SO}_{2}$ (Fig. 8). Air mass histories show that the air masses for the non-haze samples (collected on 13-15 October) originated from northeastern China and Yellow Sea, with a higher wind speed (Fig. 2a and b). When they passed over the regions, they might also have carried sea-salt and mineral dust reacted with anthropogenic $\mathrm{NO}_{\mathrm{x}} / \mathrm{HNO}_{3}$ (Geng et al., 2009a,b). However, on haze days, although nitrate-containing species are still predominant for the reacted sea-salt and reacted mineral dust particles in $\mathrm{PM}_{2.5-10}$ fraction, sulfatecontaining particles are the most abundant in $\mathrm{PM}_{1.0-2.5}$ fraction, greatly outnumbering the nitrate- and bothcontaining ones, which implies that the sources or for-
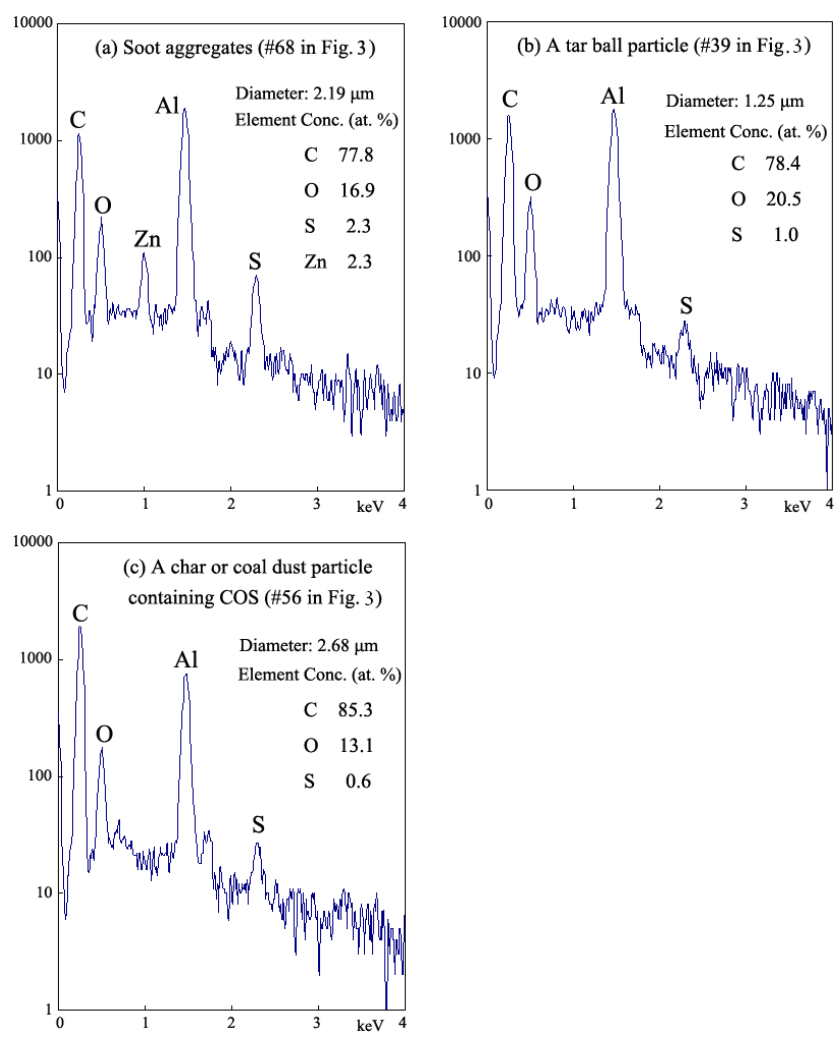

Fig. 4. X-ray spectra and atomic concentrations of carbon-rich particles (Al X-ray peaks are from collecting substrates).
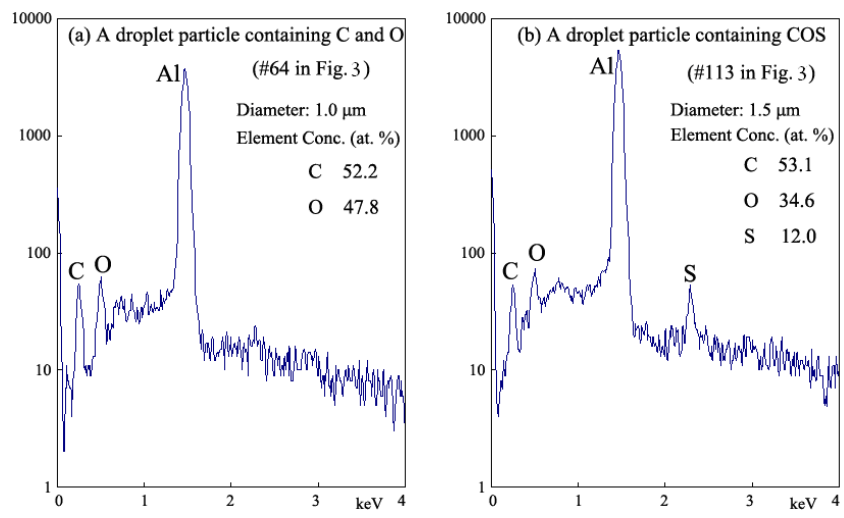

Fig. 5. X-ray spectra and atomic concentrations of organic carbon (OC) particles (Al X-ray peaks are from collecting substrates).

mation mechanisms for the reacted fine aerosol particles (less than $2.5 \mu \mathrm{m}$ in diameter) are different from those for particles in $\mathrm{PM}_{2.5-10}$ fraction. For the haze samples collected on 16-18 October 2008, the air masses originated from the sea near the west coast of Korea and lingered over the area near Incheon with low wind speed (Fig. 2c and d). So, the aerosol particles were likely 


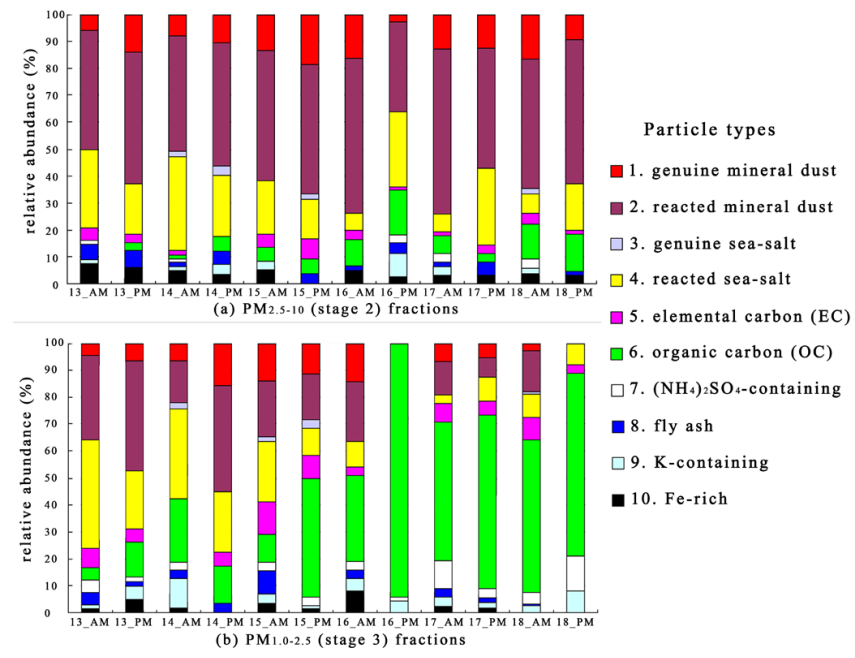

Fig. 6. Relative abundances of different particle types for the 12 sets of samples.

influenced by local air pollutants. On haze days, local $\mathrm{SO}_{2}$ concentrations were higher than those on non-haze days (Fig. 8), so that the fine sea-salt and mineral dust particles had more opportunity to react with $\mathrm{SO}_{2}$.

Further researches should be done to understand more clearly why OC particles were significantly enhanced on haze days in Incheon. Another probable cause could be due to barbecue parties popularly held during autumn events in Korea, where a significant amount of OC aerosols can also be emitted (Ryu et al., 2004).

\section{Conclusions}

On 15-18 October 2008, a typical haze event occurred in Incheon, where wind speed was low, relative humidity was high and mass concentration of inhalable particulate matter $\left(\mathrm{PM}_{10}\right)$ was increased, leading to low visibility. The haze and non-haze aerosol samples were analysed by using low-Z particle EPMA, a quantitative EDEPMA technique. The results showed that (a) carbonaceous (including EC and $\mathrm{OC}$ ), sea-salt, mineral dust, $\mathrm{K}$ containing, Fe-rich, $\left(\mathrm{NH}_{4}\right)_{2} \mathrm{SO}_{4} / \mathrm{NH}_{4} \mathrm{HSO}_{4}$-containing, and fly ash particles were the major particle types; (b) the relative number abundances of OC particles for the haze samples were significantly increased by 2.7 -fold on average in $\mathrm{PM}_{2.5-10}$ fraction and 3.5-fold in $\mathrm{PM}_{1.0-2.5}$ fraction when compared with those for the non-haze samples; (c) there were no significant differences in abundance between haze and non-haze samples for EC, genuine seasalt and mineral dust, $\mathrm{K}$-containing, $\left(\mathrm{NH}_{4}\right)_{2} \mathrm{SO}_{4} / \mathrm{NH}_{4} \mathrm{HSO}_{4}-$ containing, and fly ash particles; (d) on non-haze days, the nitrate-containing sea-salt and mineral dust particles
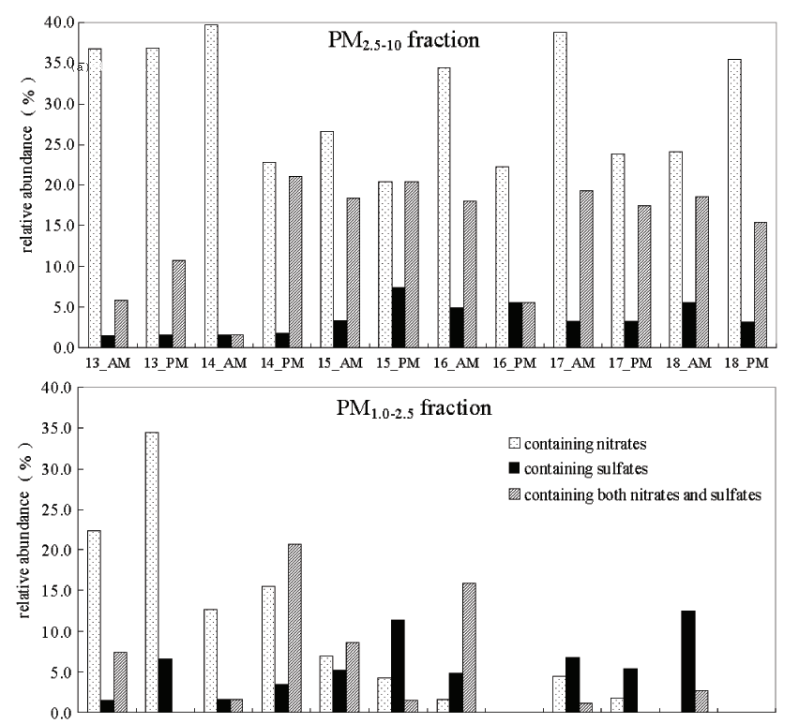

(a) 13_AM 13_PM 14_AM 14_PM 15_AM 15_PM 16_AM 16_PM 17_AM 17_PM 18_AM 18_PM
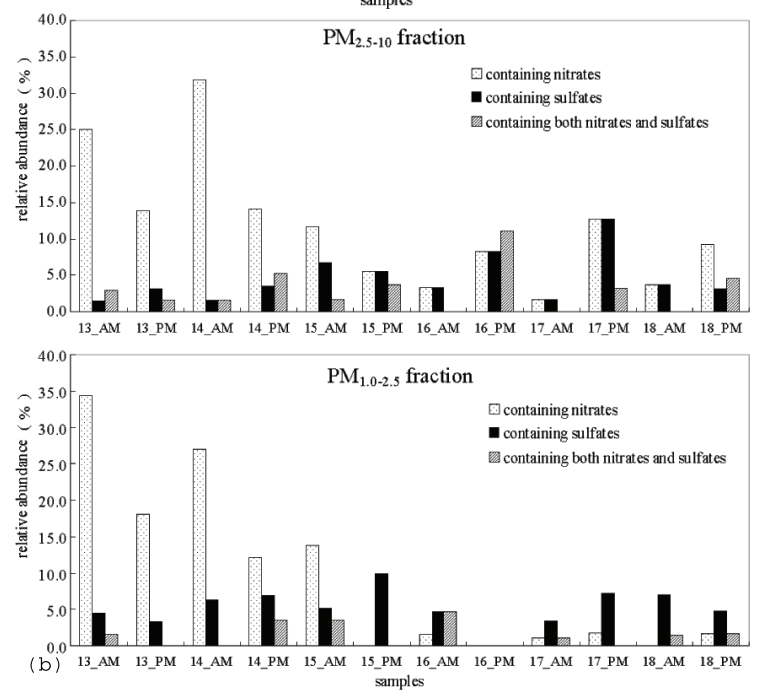

Fig. 7. Relative abundances of (a) reacted mineral dust and (b) reacted sea-salt particles, containing nitrates, sulfates and both.

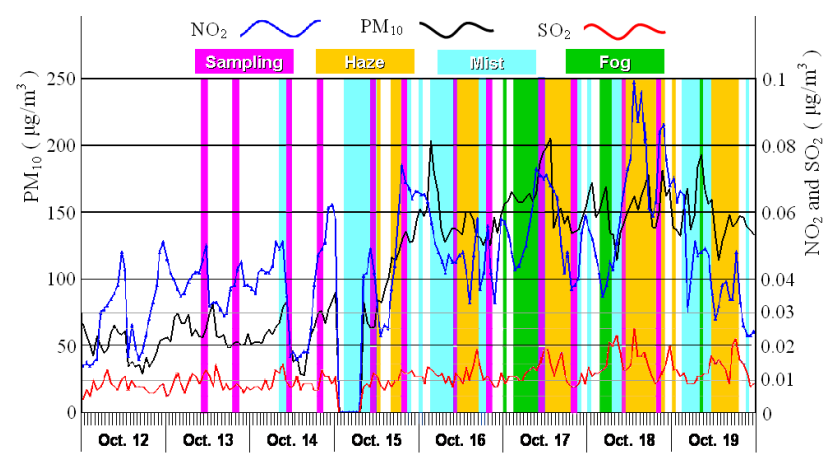

Fig. 8. Mass concentrations $\left(\mu \mathrm{g} / \mathrm{m}^{3}\right)$ of air pollutants $\left(\mathrm{PM}_{10}, \mathrm{SO}_{2}\right.$ and $\mathrm{NO}_{2}$ ) on haze and non-haze days. 
in $\mathrm{PM}_{1.0-2.5}$ fraction significantly outnumbered the sulfatecontaining ones, whereas it was the reverse on haze days. Air pollutants from motor vehicles and stagnant meteorological conditions are likely responsible for the elevated level of OC particles on haze days.

Acknowledgements. This work was supported by the Korean Science and Engineering Foundation (KOSEF) grant funded by the Korea government (MOST) (ROA-2007-000-20030-0) and by the Research Project Supported by Shanxi Scholarship Council of China (2010).

Edited by: C. H Song

\section{References}

Andreae, M. O.: Soot carbon and excess fine potassium: long-range transport of combustion-derived aerosols, Science, 220, 11481151, 1983.

Brown, S. G., Herckes, P., Ashbaugh, L., Hannigan, M. P., Kreidenweis, S. M., and Collett Jr, J. L.: Characterisation of organic aerosol in Big Bend National Park, Texas, Atmos. Environ., 36, 5807-5818, 2002.

Carrico, C. M., Petters, M. D., Kreidenweis, S. M., Sullivan, A. P. , McMeeking, G. R., Levin, E. J. T., Engling, G., Malm, W. C., and Collett Jr., J. L.: Water uptake and chemical composition of fresh aerosols generated in open burning of biomass, Atmos. Chem. Phys., 10, 5165-5178, doi:10.5194/acp-10-5165-2010, 2010.

Choel, M., Deboudt, K., Osan, J., Flament, P., and van Grieken, R.: Quantitative determination of low- $Z$ elements in single atmospheric particles on boron substrates by automated scanning electron microscopy-energy-dispersive X-ray spectrometry, Anal. Chem., 77, 5686-5692, 2005.

Chun, Y. and Lim, J. Y.: The recent characteristics of Asian dust and haze events in Seoul, Korea, Meteorol. Atmos. Phys., 87, 143-152, 2004.

Chung, Y. S., Kim, H. S., and Yoon, M. B.: Observations of visibility and chemical compositions related to fog, mist and haze in South Korea, Water Air Soil Poll., 111, 139-157, 1999.

Davis, M. E., Laden, F., Hart, J. E., Garshick, E., and Smith, T. J.: Economic activity and trends in ambient air pollution, Environ. Health Perspect., 118, 614-619, 2010.

Geng, H., Jung, H.-J., Park, Y., Hwang, H., Kim, H., Kim, Y. J., Sunwoo, Y., and Ro, C.-U.: Morphological and chemical composition characteristics of summertime atmospheric particles collected at Tokchok Island, Korea, Atmos. Environ., 43, 33643373, 2009a.

Geng, H., Park, Y., Hwang, H., Kang, S., and Ro, C.-U.: Elevated nitrogen-containing particles observed in Asian dust aerosol samples collected at the marine boundary layer of the Bohai Sea and the Yellow Sea, Atmos. Chem. Phys., 9, 6933-6947, doi:10.5194/acp-9-6933-2009, 2009b.

Geng, H., Ryu, J., Jung, H.-J., Chung, H., Ahn, K. H., and Ro, C.-U.: Single-particle characterization of summertime arctic aerosols collected at Ny-Alesund, Svalbard, Environ. Sci. Technol., 44, 2348-2353, 2010.

Hara, K., Osada, K., Yabuki, M., Hashida, G., Yamanouchi, T., Hayashi, M., Shiobara, M., Nishita, C., and Wada,
M.: Haze episodes at Syowa Station, coastal Antarctica: Where did they come from?, J. Geophys. Res., 115, D14205, doi:10.1029/2009JD012582, 2010.

Hong, S. B., Kim, D. S., Ryu, S. Y., Kim, Y. J., and Lee, J. H.: Chemical characteristics of $\mathrm{PM}_{2.5}$ ions measured by a semicontinuous measurement system during the fall season at a suburban site, Gwangju, Korea, Atmos. Res., 89, 62-75, 2008.

Jacobson, M. Z.: Strong radiative heating due to the mixing state of black carbon in atmospheric aerosols, Nature, 409, 695-697, 2001.

Jung, J., Lee, H., Kim, Y. J., Liu, X., Zhang, Y., Gu, J., and Fan, S.: Aerosol chemistry and the effect of aerosol water content on visibility impairment and radiative forcing in Guangzhou during the 2006 Pearl River Delta campaign, J. Environ. Manage., 90, 3231-3244, 2009.

Kang, C. M., Lee, H. S., Kang, B. W., Lee, S. K., and Sunwoo, Y.: Chemical characteristics of acidic gas pollutants and $\mathrm{PM}_{2.5}$ species during hazy episodes in Seoul, South Korea, Atmos. Environ., 38, 4749-4760, 2004.

Keywood, M. D., Ayers, G. P., Gras, J. L., Boers, R., and Leong, C. P.: Haze in the Klang Valley of Malaysia, Atmos. Chem. Phys., 3, 591-605, doi:10.5194/acp-3-591-2003, 2003.

Kim, H. and Ro, C.-U.: Characterization of Individual Atmospheric Aerosols Using Quantitative Energy Dispersive-Electron Probe X-ray Microanalysis: A Review, Asian J. Atmos. Environ., 4, 115-140, 2010.

Kim, Y. J., Kim, M. J., Lee, K. H., and Park, S. S.: Investigation of carbon pollution episodes using semi-continuous instrument in Incheon, Korea, Atmos. Environ., 40, 4064-4075, 2006.

Kim, K. W., Kim, Y. J., and Bang, S. Y.: Summer time haze characteristics of the urban atmosphere of Gwangju and the rural atmosphere of Anmyon, Korea, Environ. Monit. Assess., 141, 189199, 2008.

Lee, Y. L. and Sequeira, R.: Visibility degradation across Hong Kong: its components and their relative contributions, Atmos. Environ., 34, 5861-5872, 2001.

Lee, K. H., Kim, Y. J., and Kim, M. J.: Characteristics of aerosol observed during two severe haze events over Korea in June and October 2004, Atmos. Environ., 40, 5146-5155, 2006.

Menon, S., Hansen, J., Nazarenko, L., and Luo, Y.: Climate effects of black carbon aerosols in China and India, Science, 297, 22502253, 2002.

Noh, Y. M., Müller, D., Shin, D. H., Lee, H., Jung, J. S., Lee, K. H., Cribb, M., Li, Z., and Kim, Y. J.: Optical and microphysical properties of severe haze and smoke aerosol measured by integrated remote sensing techniques in Gwangju, Korea, Atmos. Environ., 43, 879-888, 2009.

Ro, C.-U., Osan, J., Szaloaki, I., Oh, K. Y., and Van Grieken, R.: Determination of chemical species in individual aerosol particles using ultrathin window EPMA, Environ. Sci. Technol., 34, 30233030, 2000.

Ro, C.-U., Oh, K. Y., Kim, H. K., Kim, Y. P., Lee, S. B., Kim, K. H., Chang, H. K., Osan, J., de Hong, J., Worobiec, A., and Van Grieken, R.: Single-particle analysis of aerosols at Cheju Island, Korea, using low- $Z$ electron probe $X$-ray microanalysis: A direct proof of nitrate formation from sea salts, Environ. Sci. Technol., 35, 4487-4494, 2001.

Ro, C.-U., Osan, J., Szaloki, I., de Hoog, J., Worobiec, A., and Van Grieken, R.: A Monte Carlo program for quantitative electron- 
induced X-ray analysis of individual particles, Anal. Chem., 75, 851-859, 2003.

Ro, C.-U., Kim, H. K., and Van Grieken, R.: An expert system for chemical speciation of individual particles using low- $Z$ particle electron probe X-ray microanalysis data, Anal. Chem., 76, 13221327, 2004.

Ro, C.-U., Hwang, H., Kim, H., Chun, Y., and Van Grieken, R.: Single-particle characterization of four Asian Dust samples collected in Korea, using low- $Z$ particle electron probe X-ray microanalysis, Environ. Sci. Technol., 39, 1409-1419 2005.

Ryu, S. Y., Kim, J. E., Zhuanshi, H., Kim, Y. J., and Kang, G. U.: Chemical composition of post-harvest biomass burning aerosols in Gwangju, Korea, J. Air Waste Manage., 54, 1124-1137, 2004.

Ryu, S. Y., Kwon, B. G., Kim, Y. J., Kim, H. H., and Chun K. J.: Characteristics of biomass burning aerosol and its impact on regional air quality in the summer of 2003 at Gwangju, Korea, Atmos. Res., 84, 362-373, 2007.

Schichtel, B. A., Husar, R. B., Falke, S. R., and Wilson, W. E.: Haze trends over the United States, 1980-1995, Atmos. Environ., 35, 5205-5210, 2001.

Soleiman, A., Othman, M., Samah, A. A., Sulaiman, N. M., Radojevic, M.: The occurrence of haze in Malaysia: a case study in an urban industrial area, Pure Appl. Geophys., 160, 221-238, 2003.
Sun, Y., Zhuang, G., Tang, A. A., Wang, Y., and An, Z.: Chemical Characteristics of $\mathrm{PM}_{2.5}$ and $\mathrm{PM}_{10}$ in haze-fog episodes in Beijing, Environ. Sci. Technol., 40, 3148-3155, 2006.

Timilsina, G. R. and Shrestha, A.: Transport sector $\mathrm{CO}_{2}$ emissions growth in Asia: Underlying factors and policy options, Energ. Policy, 37, 4523-4539, 2009.

Vekemans, B., Janssens, K., Vincze, L., Adams, F., and Van Espen, P.: Analysis of X-ray spectra by iterative least squares (AXIL): new developments, X-Ray Spectrom., 23, 278-285, 1994.

Viezee, W. and Oblanas, J.: Lidar-observed haze layers associated with thermal structure in the lower atmosphere, J. Appl. Meteor., 8, 369-375, 1969.

Wang, Q., Shao, M., Liu, Y., William, K., Paul, G., Li, X., Liu, Y., and $\mathrm{Lu}, \mathrm{S}$.: Impact of biomass burning on urban air quality estimated by organic tracers: Guangzhou and Beijing as cases, Atmos. Environ., 41, 8380-8390, 2007.

Watson, J. G.: Visibility: Science and regulation, J. Air Waste Manage., 52, 628-713, 2002.

Yadav, A. K., Kumar, K., Kasim, A., Sing, M. P., Parida, S. K., and Sharan, M.: Visibility and incidence of respiratory diseases during the 1998 haze episode in Brunei Darussala, J. Air Waste Manage., 53, 946-956, 2003. 